\title{
Ground beetles (Coleoptera: Carabidae) of the Russian Far East: Additions and corrections to the Catalogue of Palaearctic Coleoptera, Volume 1 (2017)
}

\author{
Yu.N. Sundukov', K.V. Makarov ${ }^{2}$ \\ ${ }^{1}$ Federal Scientific Center of East Asia Terrestrial Biodiversity, Far East Branch of the Russian \\ Academy of Sciences, 100-letiya Vladivostoka av. 159, Vladivostok, 690022 Russia. \\ E-mail:yun-sundukov@mail.ru \\ ${ }^{2}$ Zoology and Ecology Department, Moscow Pedagogical State University, Kibalchicha Street 6, \\ Bld.5, Moscow129164 Russia.E-mail:kvmac@inbox.ru
}

\begin{abstract}
An analyis of all available information on the ground beetles of the Russian Far East published in the $2^{\text {nd }}$ edition of the first volume of the Catalogue of Palaearctic Coleoptera is presented. A total of 155 Far Eastern taxa of Carabidae is included, for which 178 changes are given: 108 of them concern distribution data, while 70 require taxonomic corrections. Another 8 omitted Far Eastern taxa are added to the catalogue; 31 and 19 taxa are included in or excluded from the fauna of the Far East, respectively; the distribution information is either restricted or expanded for 46 taxa. The total number of species-rank taxa in the fauna of the Far East is increased from 761 to 781.

How to cite this article: Sundukov Yu.N., Makarov K.V. 2019. Ground beetles (Coleoptera: Carabidae) of the Russian Far East: Additions and corrections to the Catalogue of Palaearctic Coleoptera, Volume 1 (2017) // Invert. Zool. Vol.16. No.3. P.283-304. doi: 10.15298/invertzool.16.3.07
\end{abstract}

KEY WORDS: Taxonomic list; omitted taxa; distribution; added taxa; excluded taxa; taxonomic refinements; regional biodiversity.

\section{Жужелицы (Coleoptera: Carabidae) Дальнего Востока России: Дополнения и исправления к Catalogue of Palaearctic Coleoptera, Volume 1 (2017)}

\section{Ю.Н. Сундуков ${ }^{1}$, К.В. Макаров²}

\footnotetext{
${ }^{1}$ Федеральный научный иентр биоразнообразия наземной биоты Восточной Азии Дальневосточного отделения РАН, просп. 100-летия Владивостока, 159, Владивосток, 690022 Poccuя.E-mail:yun-sundukov@mail.ru

${ }^{2}$ Кафедра зоологии и экологии Института биологии и химии, Московский педагогический государственный университет, ул. Кибальчича 6, стр. 3, Москва 129164 Россия.

E-mail:kvmac@inbox.ru
}

РЕЗЮМЕ: Проанализирована вся доступная информация о жужелицах Дальнего Востока России, приведённых во 2-м издании первого тома Catalogue of Palaearctic Coleoptera. Для 155 дальневосточных таксонов Carabidae дано 178 изменений: 108 из них касаются данных о распределении, а 70 - таксономические исправления. В каталог добавлены еще 8 пропущенных дальневосточных таксонов; 31 таксон включен, а 19 таксонов — исключены из фауны Дальнего Востока, соответственно; инфор- 
мация о распространении либо ограничена, либо расширена для 46 таксонов. Общее количество видовых таксонов в фауне Дальнего Востока увеличено с 761 до 781.

Как цитировать эту статью: Sundukov Yu.N., Makarov K.V. 2019. Ground beetles (Coleoptera: Carabidae) of the Russian Far East: Additions and corrections to the Catalogue of Palaearctic Coleoptera, Volume 1 (2017) // Invert. Zool. Vol.16. No.3. P.283-304. doi: 10.15298/invertzool.16.3.07

КЛЮЧЕВЫЕ СЛОВА: таксономический список; пропущенные таксоны; распространение; добавленные таксоны; исключённые таксоны; таксономические уточнения; региональное биоразнообразие.

\section{Introduction}

In the autumn of 2017, the second edition of the first volume of the Catalogue of Palaearctic Coleoptera was published (Löbl, Löbl, 2017). It contains 689 species and 72 subspecies of the family Carabidae from Russian Far East. An analysis of the list presented in the catalogue allows for some clarifications to be made concerning the distribution and taxonomy, as well as certain information about the taxa omitted from the catalogue to be added.

\section{Methods}

In the Catalogue of Palaearctic Coleoptera, the Russian Far East is one of three subdivisions of the Asian part of Russia, being referred to as "FE" (Löbl, Löbl, 2017). When correcting or refining the data on the distribution of ground beetles, we used that very territorial division of Russia (Fig.).

In the course of the study, we used only published data on the distribution of ground beetles in the Far East of Russia, supported by material from the collections of the Federal Scientific Center of East Asia Terrestrial Biodiversity (Vladivostok), the Federal Pedagogical University (Moscow), and the Zoological Institute of the Russian Academy of Sciences (St. Petersburg).

To verify the taxonomic information, primary literature sources containing the descriptions of the relevant ground beetles taxa were consulted. All taxa included in the present paper are listed with reference to the pages they were published on in the catalogue.
In order not to increase the list of references, only sources used by us are included in this work, references to which being given in parentheses, ().

\section{Results}

A total of 155 Far Eastern taxa is included in this paper, for which 178 changes are given: 108 of them concern distributions, while 70 are with corrected taxonomic information.

Distributional clarifications contain information on 31 taxa included in the fauna of the Russian Far East, 19 are excluded from the fauna, as well as 9 and 38 taxa for which the distributions within and beyond the territory of the Far East are refined, respectively.

Taxonomic information contains the following data:

-6 omitted taxa added to the catalogue;

- subspecies added to 3 monotypic species;

- 1 subspecies given as a synonym;

- 3 taxa transferred to another genus;

- the type species corrected for 1 subgenus;

- the original generic combination corrected for 12 taxa;

- literature sources of original descriptions corrected for 9 taxa;

- description pages corrected for 29 taxa;

- misprints corrected for 4 taxa.

In addition, the list includes 21 Far Eastern taxa for which the description pages are unclear, as well as 21 taxa from other regions of Asia, in which misprints or other inconsistencies are noted. 


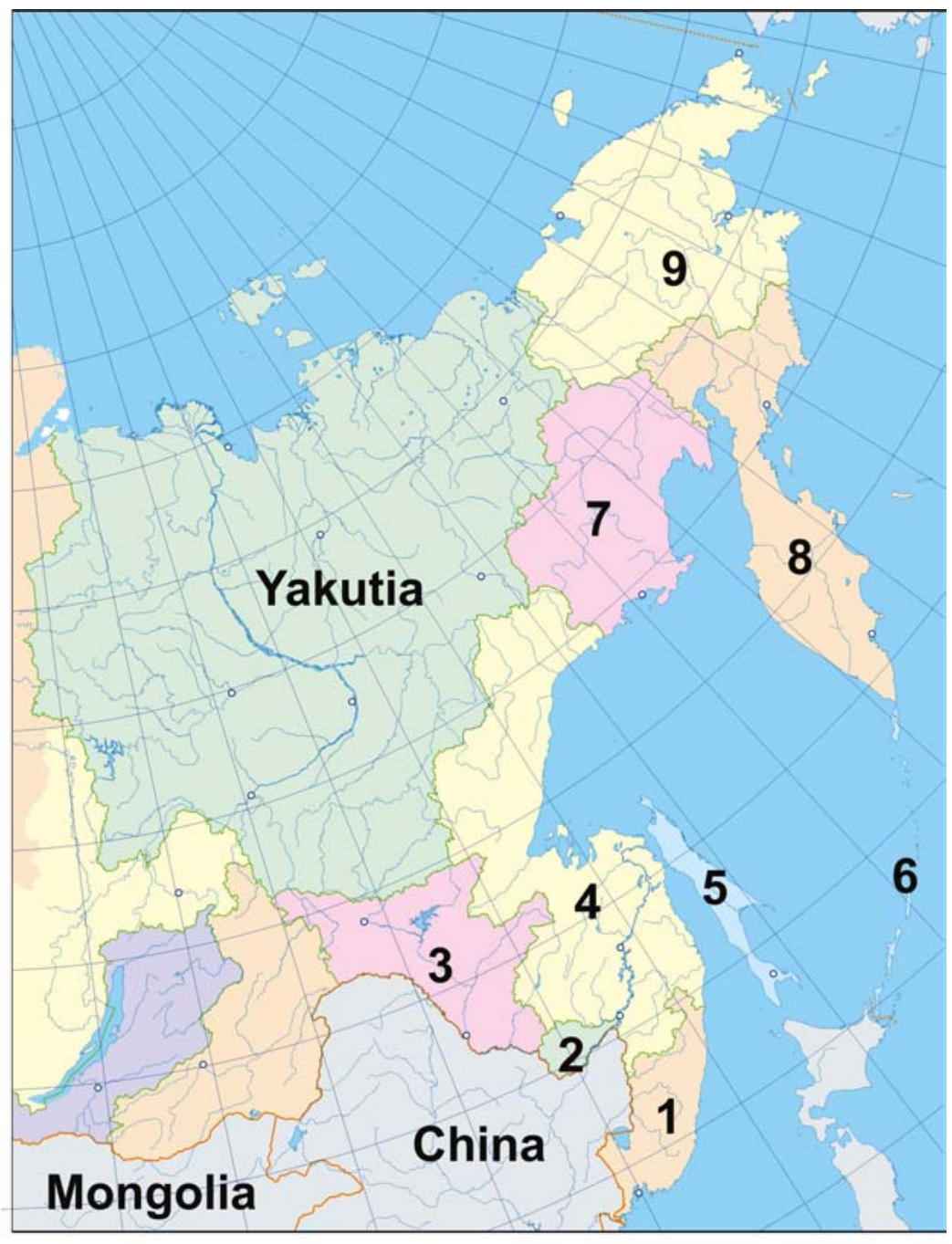

Fig. A schematic map of the Russian Far East (after Löbl, Löbl, 2017), with a detailed regionalization: 1 Primorsky Krai; 2 - Jewish Autonomous Region; 3 - Amurskaya oblast'; 4 - Khabarovsky Krai; 5 Sakhalin Island; 6 - Kurile Islands; 7 - Magadanskaya oblast'; 8 - Kamchatka; 9 - Chukotka.

Рис. Схематическая карта Дальнего Востока России (по Löbl, Löbl, 2017), с обозначениями регионов: 1 - Приморский край; 2 - Еврейская автономная область; 3 - Амурская область; 4 - Хабаровский край; 5 - о. Сахалин; 6 - Курильские острова; 7 - Магаданская область; 8 - Камчатка; 9 Чукотка.

Corrections and addition to the Far Eastern taxa of Carabidae

p. 43: Nebria (Boreonebria) gyllenhali gyllenhali (Schönherr, 1806), synonym attenuata Motschulsky, 1844: 127; change page to: 1844 :
128. Page 127 contains the beginning of the paragraph concerning to the section on Nebria brevicollis. It tells that there is a specimen from Kamchatka in the Motschulsky collection which is similar to brevicollis ... However, the name attenuata and its morphological characteristics are given only on page 128 (Motschulsky, 1844). 
p. 44: Nebria (Boreonebria) nivalis nivalis (Paykull, 1790), synonym obscuripes Poppius, 1906a: 19; change page to: 1906a: 21 (Poppius, 1906).

p. 45: Nebria (Catonebria) catenulata Fischer von Waldheim, 1820: 6; change page to: 1820: pl. vi (Fischer von Waldheim, 1820).

p. 51: Nebria (Nebria) brevicollis (Fabricius, 1792); delete FE. Not recorded from the Far East of Russia. Confirmed by material, the eastern range limit of which does not reach the Urals.

p. 56: Nebria (Paranebria) livida angulata Bänninger, 1949; add JA. The catalogue erroneously states that the nominative subspecies $N$. livida livida (Linnaeus, 1758) occurs in Japan, whereas only the subspecies angulata is found to inhabit East Asia (Shilenkov, 1975).

p. 61: Notiophilus fasciatus Mäklin, 1855; add JA. Location: Hokkaido: Shirataki (Barševskis, 2007; Suzuki, 2018).

p. 67: Calosoma (Calosoma) lugens Chaudoir, 1869f: 377; change page to: 1869f: 372 (Chaudoir, 1869).

p. 68: Calosoma (Calosoma) maximoviczi A. Morawitz, 1863: 20 (Calosoma); correct the name to maximowiczi, and change the genus from Calosoma to Carabus. Described as Carabus (Calosoma) Maximowiczi (Morawitz, 1863).

p. 70: Carabus (Acoptolabrus) constricticollis constricticollis Kraatz, 1886, synonym latioricollis Mandl, 1954b: 397 (Carabus); change the genus from Carabus to Acoptolabrus (Mandl, 1954).

p. 72: Carabus (Acoptolabrus) schrenckii schrenckii Motschulsky, 1860c: 99 (Carabus); change the genus from Carabus to Coptolabrus. Described as Coptolabrus Schrenckii Ménétr. (Motschulsky, 1860). p. 91: Carabus (Aulonocarabus) canaliculatus canaliculatus M.F. Adams, 1812; delete NC. The nominative subspecies $C$. canaliculatus does not occur in the Korean Peninsula, being separable by the subspecies careniger Chaudoir, 1863, dacatrai Deuve, 1991, deniskeithi A. Müller, 2002, hailinenesis Deuve et Li, 2000, jankowskiellus Deuve, 1991, rufinus Beheim et Breuning, 1943, sichotensis Born, 1914 and victorianus Obydov, 1997 (Březina et al., 2017).

p. 91: Carabus (Aulonocarabus) canaliculatus diamesus Semenov et Znojko, 1932; add FE (Lower Amur Region). Type locality: "vic. Rykovsko, in valle fluvii Tym riv. Botshi in jugo Sichota-alin" (= Kirovskoe on Tym River, northern Sakhalin, and Botchi River, northeastern Sikhote-Alin) (Semenov, Znojko, 1932: 218); Khabarovsky Krai: Lake Udyl' and Lake Chlya (Sundukov, 2013).

p. 91: Carabus (Aulonocarabus) canaliculatus pseudocareniger Deuve, 1991; add FE. Locations: West and south-west of Primorsky Krai (Sundukov, 2013).

p. 92: Carabus (Aulonocarabus) truncaticollis truncaticollis Eschscholtz, 1833; add ES. See: C. (Eucarabus) lenaensis Mandl, 1955 (= C. truncaticollis truncaticollis Eschscholtz, 1833); type locality: “fl. Lena”, Lena River, Yakutia (Mandl, 1955).

p. 95: Carabus (Carabus) arvensis faldermanni Dejean, 1830, synonym bellus Kraatz, 1886c: 266; change page to: $1886 \mathrm{c}: 265$. Both the description of diagnostic features and var. bellus Kraatz are presented on page 265; page 266 contains a key to variations (var.) of $C$. conciliator Fischer von Waldheim, 1820 (Kraatz, 1886).

p. 95: Carabus (Carabus) arvensis faldermanni Dejean, 1830, synonym nigerrimus Kraatz, 1886c: 266; change page to: $1886 \mathrm{c}$ : 265 . Both the description of diagnostic features and var. nigerrimus Kraatz are presented on 
page 265; page 266 contains a key to variations (var.) of C. conciliator Fischer von Waldheim, 1820 (Kraatz, 1886).

p. 98: Carabus (Carabus) granulatus yezoensis Bates, 1883; add FE (Kurile Islands). Locations: Iturup, Kunashir and Shikotan islands (Kuwayama, 1967; Krivolutskaja, 1973; Kryzhanovskij et al., 1975; Mordkovich, 2003; Lafer, 2006; Sundukov, Makarov, 2013).

p. 104: Carabus (Chaetomelas) morawitzi koltzei Roeschke, 1907a:231 (Carabus); change to: Cychrus (Cychrus) morawitzi koltzei Roeschke, 1907a: 231 (Cychrus) (Roeschke, 1907). The remaining taxa listed on this page as " $\mathrm{Ca}$ rabus (Chaetomelas) morawitzi..." should also be assigned to the genus Cychrus.

p. 104: Carabus (Chaetomelas) morawitzi morawitzi Géhin, 1885: 75 (Carabus); change to: Cychrus (Cychrus) morawitzi morawitzi Géhin, 1885: 75 (Cychrus) (Géhin, 1885).

p. 114: Carabus (Damaster) blaptoides simuschirensis Obydov, 2008: 25; a junior synonym of Carabus (Damaster) blaptoides rugipennis (Motschulsky, 1861) (Makarov, Sundukov, 2016: 48).

p. 122: Carabus (Hemicarabus) macleayi macleayi Dejean, 1826, synonym coreensis Breuning, 1933b: 856; change page to: $1933 \mathrm{~b}$ : 857 (Breuning, 1933).

p. 123: Carabus (Homoeocarabus) maeander maeander Fischer von Waldheim, 1820: 10; change page to: 1820: pl. x (Fischer von Waldheim, 1820).

p. 124: Carabus (Homoeocarabus) maeander paludis Géhin, 1885; add FE (Kamchatka). Type locality: "Sibirie", Kamtschatka (Breuning, 1932: 103).

p. 142: Carabus (Megodontus) vietinghoffii fulgidus Fischer von Waldheim, 1828; add ES. Type locality: "Dahuria", Zabaykalsky Krai
(Fischer von Waldheim, 1828: 229); lectotype in the Zoological Museum of Moscow University (Obydov, 1999).

p. 197: Carabus (Tomocarabus) fraterculus fraterculus Reitter, 1895; delete ES. In Russia, it occurs only in the extreme southwest of Primorsky Krai (FE).

p. 199: Carabus (Trachycarabus) latreillei latreillei Fischer von Waldheim, 1820: 4; change page to: 1820: pl. iv (Fischer von Waldheim, 1820).

p. 250: genus Diacheila Motschulsky, 1844: 13; change page to: 1844: 74 (Motschulsky, 1844).

p. 251: Diacheila polita Faldermann, 1835b: 360 (Blethisa); correct: polita Faldermann, 1835b: 360 [Faldermann, 1835a: 3, 23]. Described in two editions of the same work (Faldermann, 1835a, b).

p. 252: Elaphrus (Neoelaphrus) uliginosus Fabricius, 1792; delete FE. No published data from the Far East of Russia.

p. 256: Clivina (Clivina) westwoodi Putzeys, 1867; add FE. Location: southern Sikhote-Alin (Lafer, 1996; Sundukov, 2009a, 2013).

p. 263: Dyschirius (Chiridysus) rufimanus A. Fleischer, 1898; delete FE. No published data from the Far East of Russia.

p. 266: Dyschirius (Dyschiriodes) fassatii Kult, 1949; add the subspecies fassatii fassatii Kult, 1949. For a polytypic species, you must add the name of the nominative subspecies (Fedorenko, 2003).

p. 266: Add the following: Dyschirius (Dyschiriodes) fassatii koreanus Fedorenko, 2003: 372 A: SC. Type locality: "Korea, Chungkongbukdo Prov., Dang-jin City, Suk-moon seamall" (Fedorenko, 2003).

p. 268: Dyschirius (Dyschiriodes) yezoensis yezoensis Bates, 1883: 223; change page to: 1883: 232 (Bates, 1883). 
p. 268: Dyschirius, subgenus Dyschirius Bonelli, 1810, synonym Dyschiridius Jeannel, 1941a: 263; change page to: 1941a: 260 . To be correct, the beginning of the description is on page 260, where Jeannel introduced the name and the type species "Dyschiridius nov.; type: arenosus Stephens"; on page 262 the characteristic features of the genitalia of the new subgenus were given (that is, the diagnosis); page 263 contains a key to the subgenera (Jeannel, 1941).

p. 272: Dyschirius (Eudyschirius) ussuriensis Fedorenko, 1991: 149(Dyschiriodes); change the genus from Dyschiriodes to Dyschirius (Fedorenko, 1991).

p. 276: Scarites (Parallelomorphus) terricola pacificus Bates, 1873; add FE. Locations: south of Primorsky Krai (Lafer, 1989), Jewish Autonomous Region (Rogatnykh, Koshkin, 2011).

p. 283: Miscodera arctica (Paykull, 1798), synonym erythropus Motschulsky, 1844: 75; change page to: 1844: 76 (Motschulsky, 1844).

p. 302: Bembidion (Blepharoplataphus) hastii C.R. Sahlberg, 1827, synonym ventricosus Motschulsky, 1850a: 11; change the reference to: 1860a: 89. See: Peryphus ventricosus Motschulsky, 1850: 11, nomen nudum, type locality “Ins. Kuril. Urupa"; described as Peryphus ventricosus Motschulsky, 1860: 89, type locality: "Kamtschatka, rivages du fl. Kodogorek" (Motschulsky, 1850, 1860).

p. 304: Bembidion, subgenus Chlorodium Motschulsky, 1864, type species Bembidium splendidum Sturm, 1825; change the type species to: Bembidium colchicum Chaudoir, 1850. See: Chlorodium Motschulsky, 1864, the type species: Bembidium colchicum Chaudoir, 1850 (= Bembidium splendidum Sturm, 1825), designated by Jeannel (1941).

p. 304: Bembidion (Chlorodium) difforme (Motschulsky, 1844), synonym posterium Gemminger et Harold, 1868 (Bembidion); change the genus from Bembidion to Bembicidium (Gemminger, Harold, 1868).

p. 308: Bembidion (Eupetedromus) sibiricum Dejean, 1831; add JA. See: Bembidion (Eupetedromus) inouyei nom. nov. sensu Netolitzky, Bembidion (Eupetedromus) sibiricum Motschulsky (= B. sibiricum) from Hokkaido, Japan (Habu, 1972: 17).

p. 309: Bembidion (Hydrium) pogonoides Bates, 1883; add FE (Sikhote-Alin). Locations: Sikhote-Alinsky Nature Reserve (Sundukov, 2003), Lazovsky Nature Reserve (Sundukov, 2009a).

p. 310: Bembidion (Melomalus) altaicum Gebler, 1833: 272 (Bembidion); change the genus of description from Bembidion to $\mathrm{An}$ chomenus (Gebler, 1833).

p. 310: Bembidion, subgenus Metallina Motschulsky, 1850a: 12; change page to: 1850a: 13 (Motschulsky, 1850).

p. 312: Bembidion (Neoemphanes) shimoyamai Habu, 1978; add FE. Locations: Primorsky Krai: Murav'eva-Amurskogo Peninsula (Lafer, 2005), Sikhote-Alinsky Nature Reserve (Sundukov, 2003), Lazovsky Nature Reserve (Sundukov, 2009a).

p. 314: Bembidion (Notaphocampa) niloticum batesi (Putzeys, 1875); add synonym niloticum Bates, 1873: 301 (Bembidion). Bates provided the morphological characteristics for $B e$ mbidium niloticum (Dejean, 1831) (Bates, 1873), which was subsequently distinguished as a separate species, Notaphus batesi nom. nov. (Putzeys, 1875). Therefore, Bembidium (Notaphus) niloticum Bates, 1873: 301, type locality: "Nagasaki", is a junior synonym of Bembidion (Notaphocampa) niloticum batesi.

p. 316: Bembidion (Ocydromus) echigonum Habu et Baba, 1957; delete FE. No published data from the Far East of Russia.

p. 317: Bembidion (Ocydromus) scopulinum (Kirby, 1837), synonym mongolicum 
Jedlička, 1967c: 105; change reference to: 1965e: 127. Described as Bembidion thermarum mongolicum ssp. nov.; type: Mongolei, Zum Chara, im Mus. Praha (Jedlička, 1965).

p. 318: Bembidion (Ocydromus) umeayi Habu, 1959; add FE. Location: southeastern Sikhote-Alin (Sundukov, 2013).

p. 324: Bembidion (Peryphus) amurense amurense Motschulsky, 1859d: 488 (Peryphus); change reference to: 1860a: 90. See: Peryphus amurensis Motschulsky, 1859: 488, nomen nudum, type locality: "fl. Amour, depuis la Schilka jusqu'a Nikolaëvsk"; described as Peryphus amurensis Motschulsky, 1860: 90, type locality: "fl. Amour aux environs de Nikolaevsk" (Motschulsky, 1859, 1860). In addition, as regards $B$. amurense, the catalogue contains an incorrect reference to Motschulsky, 1859d; that work is actually referred to in the catalogue's bibliography as Motschulsky, 1859b.

p. 324: Bembidion (Peryphus) amurense amurense (Motschulsky, 1860); delete JA. Another subspecies inhabits all Japanese islands: B. amurense trajectum Netolitzky, 1939 (Netolitzky, 1939, 1943; Yoshitake et al., 2011).

p. 325: Bembidion (Peryphus) captivorum Netolitzky, 1943; delete JA. This species does not occur in Japan, the taxon bearing that name in Japan is known as B. (Peryphus) poppii pohlai Kirschenhofer, 1984; type locality: “Japan: Kamikochi” (Kirschenhofer, 1984: 73).

p. 328: Bembidion (Peryphus) poppii pohlai Kirschenhofer, 1984; add FE. Locations: Sakhalin, South Kuriles (Lafer, 2002, 2006; Sundukov, Makarov, 2013; Sundukov, 2017).

p. 330: Bembidion (Philochthus) baicalicum (Motschulsky, 1844); add FE. Locations: Khabarovsk (Berlov, Berlov, 1997a), Primorsky Krai (Sundukov, 2013).

p. 332: Bembidion (Plataphus) coelestinum (Motschulsky, 1844); add FE. Locations: Primorsky Krai: Murav'eva-Amurskogo Peninsu- la (Lafer, 2005), southern Sikhote-Alin (Shilenkov, 1979), Sikhote-Alinsky Nature Reserve (Sundukov, 2003).

p. 333: Bembidion (Plataphus) gebleri nakanei Jedlièka, 1965; delete FE. In the Far East of Russia, it was erroneously recorded only from the Kuril Islands (Kryzhanovskij et al., 1975). A restudy of this material from the Zoological Institute, Russian Academy of Sciences (St. Petersburg, Russia) showed it to represent Bembidion pseudolucillum Netolitzky, 1938 common in the southern Kurile Islands (Sundukov, Makarov, 2013, 2016).

p. 338: Bembidion (Trichoplataphus) parconaturaviva Toledano et Schmidt, 2010; add FE NC, delete ES. Type locality: "Holotype: Primorskji Kraj, Novocugujevka; Distribution: Ussuri Region, North Korea" (Toledano, Schmidt, 2010).

p. 339: Bembidion (incertae sedis) sanatum Bates, 1883; add FE. Location: Kurile Islands: Kunashir (Sundukov, Makarov, 2016).

p. 342: genus Elaphropus Motschulsky, 1839, synonym Barytachys Chaudoir, 1868d: 213; change page to: $1868 \mathrm{~d}: 212$ (Chaudoir, 1868).

p. 343: Elaphropus latissimus latissimus (Motschulsky, 1851), synonym unistriatus Reitter, 1887g: 494; change page to: $1887 \mathrm{~g}: 497$ (Reitter, 1887).

p. 345: Tachys (Paratachys) bistriatus bistriatus (Duftschmid, 1812); delete FE. This western Palaearctic species is unknown from the Russian Far East.

p. 352: Tachyura (Tachyura) gradata Bates, 1873b: 331 (Tachyura); change the genus from Tachyura to Tachys. Described as Tachys gradatus (Bates, 1873).

p. 356: Pogonus (Pogonus) iridipennis Nicolai, 1822: 16 (Pogonus); change the genus from Pogonus to Carabus. Described as Carabus (Pogonus) iridipennis (Nicolai, 1822). 
p. 358: Perileptus japonicus Bates, 1873; add NC. Location: "Kaesong city, Kaesong; S. Hwanghae, Haeju, Mt. Suyoung-san” (Park, Széll, 2004).

p. 420: Trechus (Epaphius) densicornis (Fischhuber, 1977); add the subspecies densicornis densicornis (Fischhuber, 1977). For a polytypic species, the name of the nominative subspecies must be added (Sundukov, 2013).

p. 420: Add the following: Trechus (Trechus) densicornis khuntami Sundukov, 2013: 24 A: FE (Sikhote-Alin). Type locality: "headwaters of the Dzhigitovka River", Sikhote-Alin, Primorsky Krai (Sundukov, 2013).

p. 420: Add the following: Trechus (Trechus) densicornis sinegorensis Sundukov, 2013: 25 A: FE (Sikhote-Alin). Type locality: "Levaya Sinegorka River”, Siniy Ridge, Primorsky Krai (Sundukov, 2013).

p. 421: Trechus (Epaphius) plutenkoi kushironis Uéno, 1992; add FE. Location: South Kuriles: Yurii Island (Sundukov, 2017).

p. 423: Trechus (Trechus) apicalis Motschulsky, 1845; correct: JA (Rishiri-to Island). Known only from Rishiri-to Island, Japan, but absent from Hokkaido (Uéno, 1984; Uéno, Lafer, 1994).

p. 424: Trechus (Trechus) basarukini P. Moravec et Wrase, 1997; add the subspecies basarukini basarukini P. Moravec et Wrase, 1997. For a polytypic species, the name of the nominative subspecies must be added (Sundukov, 2013).

p. 424: Add the following: Trechus (Trechus) basarukini shokhrini Sundukov, 2013:23 A: FE (Sikhote-Alin). Type locality: "Snezhnaya Mountain", southern Sikhote-Alin, Primorsky Krai (Sundukov, 2013).

p. 439: Trechus (Trechus) nakaguroi Uéno, 1960; limited FE (Kurile Islands). In Russia, known only from Kunashir Island, southern Kuriles (Sundukov, 2001a). p. 445: Trechus (Trechus) rubens (Fabricius, 1792); delete FE. There are no records of this species from the Russian Far East. The eastern range limit in Russia is Lake Baikal (Khobrakova et al., 2014).

p. 464: Patrobus assimilis Chaudoir, 1844; add FE. Location: southern Sikhote-Alin, Sestra Mountain, Sestrinsky Stream, 1500 m elevation (Sundukov, 2013).

p. 479: Mastax thermarum egorovi Lafer, 1973: 852; change page to: 1973: 853 (Lafer, 1973).

p. 484: Chlaenius (Achlaenius) variicornis A. Morawitz, 1863; add FE, delete ES. Locations: Primorsky Krai (Kryzhanovskij, 1976; Lafer, 1989; Sundukov, 2009a, 2013), Kurile Islands (Kryzhanovskij et al., 1975; Lafer, 1989). No records from eastern Siberia (ES).

p. 484: Chlaenius (Agostenus) sulcicollis (Paykull, 1798); add FE. Location: south of Primorsky Krai (Kryzhanovskij, 1976; Sundukov, 2013).

p. 489: Chlaenius (Chlaenites) spoliatus spoliatus (P. Rossi, 1792); delete FE. The Far East supports only the East Asian subspecies Ch. spoliatus motschulskyi Andrewes, 1928 (Kryzhanovskij, 1976; Lafer, 1989).

p. 490: Chlaenius (Chlaenius) pallipes $\mathrm{Ge}-$ bler, 1823: 127 (Epomis); change page to: 1823: 128 (Gebler, 1823).

p. 491: Chlaenius (Eochlaenius) suvorovi (Semenov, 1912); add FE JA, delete ES. Type locality: "fluvii Ussuri, $20 \mathrm{~km}$ infra Nikolsk; ejusdem fluvii littora, $60 \mathrm{~km}$ infra Iman" (= Ussuri River, $20 \mathrm{~km}$ downstream Ussuriysk and $60 \mathrm{~km}$ below Iman River) (Semenov, 1912: 602-603); south of Primorsky Krai (Kryzhanovskij, 1976; Lafer, 1989; Sundukov, 2013); Honshu, Japan (Habu, 1987). No records from eastern Siberia (ES). 
p. 491: Chlaenius (Haplochlaenius) insularis Uéno, 1964; delete FE. No records from Russia. Sakhalin supports Ch. (Chlaeniellus) insularis Kryzhanovskij, 1973 (= Ch. circumductus A. Morawitz, 1862) (Kryzhanovskij, 1973).

p. 564: Acupalpus (Acupalpus) ussuriensis Lafer, 1989: 198; change page to: 1989: 199. Described in a key, the thesis beginning on page 198 , but the name of the species, the type material and the type locality appearing only on page 199 (Lafer, 1989).

p. 583: Cymindis, subgenus Cymindis Latreille, 1805, synonym Anomoeus Fischer von Waldheim, 1820: 12; change page to: $1820: 125$ (Fischer von Waldheim, 1820).

p. 584: Cymindis (Baicalotarus) rivularis Motschulsky, 1844; add FE. Location: southern Sikhote-Alin (Sundukov, 2011).

p. 596: Apristus striatus (Motschulsky, 1844); delete JA. Bates (1873) mistakenly recorded it from Japan. The truly Japanese species was later described as $A$. grandis Andrewes, 1937 (Andrewes, 1937), with A. striatus excluded from the fauna of Japan.

p. 597: Dromius (Dromius) angusticollis J.R. Sahlberg, 1880, synonym flavipes Motschulsky, 1859d: 488; change reference to: 1864: 229. See: Dromius flavipes Motschulsky, 1859: 488, nomen nudum, type locality: "du fl. Amour, depuis la Schilka jusqu'à Nikolaëvsk"; described as Dromius flavipes Motschulsky, 1864: 229, type locality: "Des rives du fl. Amour." (Motschulsky, 1859, 1864).

p. 597: Dromius (Dromius) angusticollis J.R. Sahlberg, 1880; add NC. Location: "Prov. Ryanggang, on the road from Samjiyon to Pekdu-san, 2.260-2.300 m" (Park, Széll, 2004).

p. 597: Dromius (Dromius) ater Motschulsky, 1859d: 488; change reference to: 1864 : 228. See: Dromius ater Motschulsky, 1859: 488, nomen nudum, type locality: "du fl. Amour, depuis la Schilkajusqu'à Nikolaëvsk"; described as Dromius ater Motschulsky, 1864: 228, type locality: "Des bords du fl. Amour." (Motschulsky, 1859, 1864).

p. 598: Dromius (Klepterus) prolixus Bates, 1883: 207; change page to: 1883: 282 (Bates, 1883).

p. 602: Microlestes fissuralis (Reitter, 1901); add FE. Location: Amurskaya oblast' (Rogatnykh, 2007).

p. 603: Microlestes schroederi Holdhaus, 1912: 514; correct: 1912: 38 [514]. As the page numbers in that work are duplicated: 1-64 [477$540]$, it is more correct to quote both options (Holdhaus, 1912).

p. 605: Paradromius (Manodromius) ruficollis (Motschulsky, 1844); add NC. Location: "Prov. Ryanggang, Mt. Pektusan, 1900 m"(Park, Széll, 2004).

p. 607: Philorhizus sigma (P. Rossi, 1790), synonym fasciatus Paykull, 1790: 226; change page to: 1790: 97 (Paykull, 1790).

p. 618: Setolebia caligata Bates, 1889c: 219 (Lebia); change both the reference and genus to Setolebia caligata Bates, 1888b: 382 (Lebia). Originally described as Lebia caligata (Bates, 1888). That work of 1889 discussed the following: "Lebia prattiana. — L. fuscae (Morawitz) ... "description L. fuscae" ... This species connects the Asiatic group of Lebia, in which the thorax is wholly rounded anteriorly (without anterior angles) and the outer angle of the elytral truncature dentiform, with the numerous group iv. â of Chaudoir's Monograph of the Lebiides, in which the elytral interstices are similarly convex, but the outer angle of the truncature rounded etc. L. prattiana, in fact, resembles much a large L. caligata (Bates)" (Bates, 1889). Thus, L. caligata was originally described earlier and in a different genus. In addition, the quoted piece is on page 218 , not 219 , as falsely indicated in the catalogue. 
p. 618: Parena cavipennis (Bates, 1873); add NC. Location: "Kaesong, Kaesong city, Hotel Janamsan” (Park, Széll, 2004).

p. 619: Parena monostigma (Bates, 1873); add NC. Location: "Prov. Gang-von, district On-dzong, Kumgang-san, near Hotel, Go-song, 250 m" (Park, Széll, 2004).

p. 627: Badister (Badister) pictus Bates, 1873; delete FE. There is one mention for the Far East of Russia: "finding this species is possible in Kunashir and southern Sakhalin" (Komarov, 1991). No actual records are known.

p. 628: Badister (Baudia) marginellus Bates, 1873; add FE (Kurile Islands). Locations: Kunashir, Shikotan and Yurii islands (Mordkovich, 2003; Sundukov, 2008, 2017; Sundukov, Makarov, 2013).

p. 628: Badister (Baudia) ussuriensis Jedlička, 1937; add NC. Location: North Korea: Savoron (Jedlička, 1960).

p. 640: Peronomerus fumatus Schaum, 1854; delete FE. No records from the Russian Far East.

p. 640: Pentagonica daimiella Bates, 1892; add FE NC. Locations: Jewish Autonomous Region (Kataev, 2006), southern Sikhote-Alin (Sundukov, Smirnov, 2010); "North Pyongan Prov., Mt. Myohyang-san” (Park, Széll, 2004).

p. 642: Perigona (Trechicus) nigriceps (Dejean, 1831); add ES. Location: Buryatia (Shilenkov, Anichtchenko, 1998; Sundukov, 2009b; Khobrakova et al., 2014).

p. 644: Agonum (Agonum) gracilipes (Duftschmid, 1812), synonym elongatum Fischer von Waldheim, 1823: 19; change page to: 1823: 126. The descriptions of this taxon are given on pages 126-127, while the beetle's drawing in Tab. XIX, fig. 3 (Fischer von Waldheim, 1823).

p. 646: Agonum (Europhilus) exaratum (Mannerheim, 1853); add FE. Locations: Chu- kotka, Magadanskaya oblast', Kamchatka (Lafer, 1992a).

p. 646: Add the following: Agonum (Europhilus) gratiosum gratiosum Mannerheim, 1853: 142 A: FE. Location: Chukotka (Lafer, 1992a).

p. 654: Colpodes komarovi (Lafer, 1976); change to Xestagonum komarovi (Lafer, 1976) (Sundukov, 2013).

p. 657: Eucolpodes japonicum chinadense (Jedlička, 1940); delete FE. In the Far East of Russia, E. japonicum (Motschulsky, 1861) is known to occur only on islands (South Kuriles and Sakhalin), being represented by the nominative subspecies E. japonicum japonicum (Motschulsky, 1861). This species is unknown from the mainland Far East of Russia.

p. 657: Eucolpodes japonicum japonicum (Motschulsky, 1861); add FE. Locations: Sakhalin and South Kuriles (Iturup, Kunashir, Shikotan) (Kryzhanovskij et al., 1975; Berlov, Berlov, 1997b; Lafer, 1992a, 2002; Mordkovich, 2003; Sundukov, Makarov, 2013; Vertyankin, Shabalin, 2013).

p. 658: Euplynes batesi Harold, 1877; add FE. Location: south of Primorsky Krai (Makarov, Sundukov, 2011).

p. 658: Gyrochaetostylus atricomes (Bates, 1873), synonym piceonigrum Jedlička, 1936d: 50; change piceonigrum to piceoniger (Jedlička, 1936b).

p. 661: Lissagonum lampros (Bates, 1873); add FE. Location: Kurile Islands: Kunashir (Makarov, Sundukov, 2011).

p. 667: Platynus mannerheimii (Dejean, 1828), synonym octofoveolatus Mäklin, 1857: 338; change reference to: 1855 : 34 . The 1857 publication is a translation from Swedish to German, dated 1855 (Mäklin, 1855, 1857).

p. 674: Xestagonum shokrini Sundukov, 2013: 154; change shokrini to shokhrini, and change page to: 2013: 46 (Sundukov, 2013). 
p. 697: Poecilus (Poecilus) samurai (Lutshnik, 1916); add FE (Sakhalin). Location: southern Sakhalin (Lafer, 1989).

p. 698: Poecilus (Poecilus) versicolor (Sturm, 1824); add JA. A junior synonym, Poecilus planicollis Motschulsky, 1861, was described from Japan (Motschulsky, 1861: 5).

p. 701: Pterostichus (Badistrinus) haptoderoides japanensis (Lutshnik, 1922); add FE. Locations: Kurile Islands (Iturup, Kunashir, Shikotan) and Sakhalin (Krivolutskaja, 1973; Kryzhanovskij et al., 1975; Lafer, 2002; Sundukov, Makarov, 2013; Vertyankin, Shabalin, 2013).

p. 701: Pterostichus (Bothriopterus) adstrictus Eschscholtz, 1823; add JA. Locations: Abashiri, Hokkaido (Sasakawa, Kubota, 2007), Obihiro, Hokkaido (Kaizuka, Iwasa, 2014), etc.

p. 707: Pterostichus (Cryobius) kaninensis kurnakovi G.E. Ball, 1966; add FE. Location: Chukotka: Wrangel Island (Khruleva, 1987).

p. 708: Pterostichus (Cryobius) korgei Jedlička, 1964; delete FE. No records from the Russian Far East.

p. 708: Pterostichus (Cryobius) kurosawai Tanaka, 1958; add JA. Location: Hokkaido: Daisetsu Mts, Rishiri Island (Morita, 2002).

p. 708: Pterostichus (Cryobius) nivalis (R.F. Sahlberg, 1844); add FE. Type locality: "In monte Morikan sub lapidibus, nin....adhuc tectis, capta", Ayan, Khabarovsky Krai (Sahlberg, 1844:37-39); Kamchatka(Ball, 1966), Chukotka (Erjiomin, 1998).

p. 711: Pterostichus (Eosteropus) coruscus (Tschitschérine, 1895); add FE. Location: south of Primorsky Krai: Furugelma Island (Lafer, 2004).

p. 712: Add the following: Pterostichus (Eosteropus) orientalis nigromontanus Lafer et
Budilov, 2015: 102 A: FE. Type locality: Primorsky Krai, Khasansky distr., Kedrovaya Pad' Nature Reserve (Lafer, Budilov, 2015).

p. 714: Pterostichus (Feroperis) sungariensis Lafer, 1979; add HEI. Type locality: "the mouth of Sungari River", Heilongjiang, China (Lafer, 1979: 26-27). The subsequent discovery of this species in the Amur region of Russia did not exclude its occurrence in China, but only raised the question of its taxonomic relationship with Pterostichus melanodes (Chaudoir, 1878) (Lafer, 1992b).

p. 717: Pterostichus, subgenus Koreonialoe Park et Kwon, 1996, synonym Natalianoe O. Berlov et Plutenko, 1997: 4; change page to: 1997: 50 (Berlov, Plutenko, 1997).

p. 717: Pterostichus, subgenus Lenapterus O. Berlov, 1996, synonym Galapterus O. Berlov et Plutenko, 1997: 3; change page to: 1997: 47 (Berlov, Plutenko, 1997).

p. 717: Pterostichus (Lenapterus) costatus (Ménétriés, 1851); add NT WS. A Holarctic polar species: the tundra zone from Gydanskii Peninsula in the north of Eurasia to Hudson Bay in North America (Sundukov, 2005).

p. 720: Pterostichus (Melanius) licenti Jedlička, 1939; delete FE. Erroneously recorded from the Far East of Russia in the catalogue of the ground beetles of Russia (Kryzhanovskij et al., 1995). This information may have been used in the Catalogue of Palaearctic Coleoptera (Bousquet, 2003, 2017).

p. 720: Pterostichus (Metallophilus) kamtschaticus alexejevi Brinev, 2001; add ES, delete FE. Distribution: Central Yakuria(Brinev, Shilenkov, 2001).

p. 720: Pterostichus (Metallophilus) kamtschaticus kamtschaticus Motschulsky, 1860; delete ES. Known only from Kamchatka (Brinev, Shilenkov, 2001). 
p. 720: Pterostichus (Metallophilus) pfizenmayeri Poppius, 1906; add FE. Distribution: Yakutia to the west of Yakutsk and SuntarKhayata Ridge (Brinev, Shilenkov, 2001).

p. 720: Pterostichus (Metallophilus) sublaevis (J.R. Sahlberg, 1880); add FE, delete NT. Distributed from Yamal Peninsula (WS) to Chukotka (FE) (Brinev, Shilenkov, 2001).

p. 732: Pterostichus (Petrophilus) nigellus A. Morawitz, 1862; delete ES. Type locality: "Bai De Castries", Khabarovsky Krai (Morawitz, 1862: 214[255]); "a syntype from USSR (Habarovsk kraj): De Castries B., Arthur N." (Silfverberg, 1987: 21). Known only the syntype (Sundukov, 2013).

p. 733: Pterostichus (Phonias) diligens (Sturm, 1824); add FE. Locations: Kurile Islands, Kamchatka, Sakhalin, Moneron Island (Berlov, Berlov, 1997b; Lafer, 2002, 2006; Sundukov, Makarov, 2013; Vertyankin, Shabalin, 2013; Sundukov, 2014, 2017).

p. 734: Pterostichus (Phonias) kutensis Poppius, 1905; add FE. Location: Khabarovsky Krai: northern Amur Region (Lyubechanskii et al., 2006; Budilov, 2016; Koshkin et al., 2016; Kuberskaya, Mutin, 2016).

p. 735: Pterostichus (Phonias) sotkaensis Jedlička, 1958; delete FE. Excluded from fauna of the Russian Far East (Pterostichus sotkaensis auct. = Pterostichus (Pledarus) larisae Sundukov, 2013) (Sundukov, 2013).

p. 747: Pterostichus (incertae sedis) marginatus Matsumura, 1911; limited FE (Sakhalin). Originally described from Sakhalin (Matsumura, 1911), mentioned in the list of South Sakhalin beetles (Yokayama, Kanô, 1927). As it was not found later, it was excluded from the fauna of Sakhalin as an unclear taxon (nomen dubium) (Lafer, 2011).

p. 764: Calathus, subgenus Neocalathus Ball et Nègre, 1972, type species: Carabus malano- cephalus Linnaeus, 1758; change malanocephalus to melanocephalus.

p. 769: Dolichus halensis (Schaller, 1783); add SCH YUN. Junior synonyms were described from Sichuan and Yunnan: Dolichus bicolor Maindron, 1910 (de Yunnan Sen et de Tali), Dolichus viduus Maindron, 1910 (Yunnan), Dolichus viduus ab. phaeopus Maindron, 1910 (Yunnan), Dolichus rufithorax Jedlička, 1936 (Tatsienlu, Sichuan), Dolichus rufithorax ab. pictus Jedlička, 1936 (Pingshiang), Dolichus viduus ab. brunneipennis Jedlička, 1936 (Yunnan), Dolichus viduus ab. triangularis Jedlička, 1936 (Tatsienlu, See Tsong, Sichuan), Dolichus phaeopus ab. limbatus Jedlička, 1936 (Szetschuan), Dolichus phaeopus ab. szetschuanus Jedlička, 1936 (Kiating, Sichuan) (Maindron, 1910; Jedlička, 1936a).

p. 785: Pseudotaphoxenus dauricus dauricus (Fischer von Waldheim, 1823); delete FE. Erroneously recorded from the Far East of Russia (Casale, 1988; Kryzhanovskij et al., 1995). The confusion was probably caused by the label "all'Ussuri ad Est" (Casale, 1988), based on Taphoxenus ussuriensis Jedlička, 1953 (= Pseudotaphoxenus dauricus dauricus), type locality: "Transbaikal, Werchne-Udinsk" (= Ulan-Ude, Buryatia) (Jedlička, 1953).

p. 791: Synuchus (Synuchus) arcuaticollis (Motschulsky, 1861); add FE (Kamchatka, Sakhalin). Locations: Kamchatka, Sakhalin(Lafer, 1989, 2002; Berlov, Berlov, 1997b; Vertyankin, Shabalin, 2013).

p. 792: Synuchus (Synuchus) crocatus (Bates, 1883); delete FE. It was erroneously recorded in the fauna of Russia only from the Kunashir Island, southern Kurile Islands (Kryzhanovskij et al., 1975). Subsequent authors referred to these data (Habu, 1978; Hovorka, Sciaky, 2003), although this species was long excluded from the fauna of Russia (Kryzhanovskij et al., 1995). There are no later publications concernig S. crocatus in Russia.

p. 792: Synuchus (Synuchus) orbicollis A. Morawitz, 1862, synonym cycloderus Heyden, 
1886c: 270 (Synuchus); change the genus Synuchus to Calathus. Originally described as $\mathrm{Ca}$ lathus cycloderus (Heyden, 1886).

p. 796: Amara (Amara) communis Panzer, 1797e: 40 no 2 (Carabus); change the year and page to: 1796g: no. 2 (Panzer, 1796). The catalogue contains further three references to "Panzer, 1797" (for the type species of Parapoecilus, the genus Amara, and the subgenus Amara), although there is no citation of Panzer 1797 contained in the bibliography list.

p. 798: Amara (Amara) kingdonoides Hieke, 2002; add ES NC WS (Altai). Locations: "Im sibirischen Tiel von Russland: Altaj, West- und Ostsajan-Gebirge bis nach Jakutien und Gebiet Magadan; im Gebiet Irkutsk, in Transbaikalien und Amur-Gebiet. Im Ussuri-Gebiet im SichoteAlin-Gebirge. Auch auf Sachalin und in den Bergen des nordlichen Korea" (Hieke, 2002).

p. 806: Amara (Bradytus) aurichalcea Germar, 1823; delete JA. There are no records of this species from Japan.

p. 807: Amara (Bradytus) fritzhiekei Sundukov, 2013: 165 (Bradytus); change the genus of description Bradytus to Amara (Sundukov, 2013).

p. 807: Amara (Bradytus) pseudosimplicidens Lafer, 1980; add NC. Paratype: "Democratic People's Republic of Korea, 2 \%, Di Don-Yur leg." (Lafer, 1980).

p. 809: Amara (Celia) laticarpa Bates, 1873; add BEI JA HEI MG SHA QIN. Type locality: "Hiogo", Japan (Bates, 1873: 293); distribution: "Baikal-Gebiet, Transbaikalien, Amur-und Ussuri-Gebiet, Japan, N. Korea, N. und NO. China (Mandshurei, Umgebung von Peking, Shaanxi, Qinghai), O. Mongolei”(Hieke, 2000).

p. 810: Amara (Celia) pseudobrunnea Lindroth, 1968; delete FE. There are no records of this species from the Far East of Russia. p. 810: Amara (Celia) saginata vilis Tschitschérine, 1894; delete JA. A. saginata Ménétriés, 1848 was recorded from Japan and referred to as a senior synonym of A. laticarpa Bates, 1873. Both are quoted in the Catalogue as two separate species.

p. 814: Amara (Curtonotus) kataevi Sundukov, 2001: 440 (Amara); change the genus of description Amara to Curtonotus (Sundukov, 2001b).

p. 814: Amara (Curtonotus) larisae Sundukov, 2001: 437 (Amara); change the genus of description Amara to Curtonotus (Sundukov, 2001b).

p. 824: Amara (Reductocelia) arcticola Poppius, 1906; add FE. Locations: Bulun on Lena River and Yakutsk, Yakutia; Omsukchan in Magadanskaya oblast'; Wrangel Island, Chukotka (Hieke, 1999); Wrangel Island (Khruleva, 1987).

p. 824: Amara (Reductocelia) colvillensis Lindroth, 1968; add ES. Locations: Zhigansk and Kyzyr on Lena River, and Olenek River, Yakutia (Hieke, 1999).

p. 825: Amara, subgenus Xenocelia Hieke, 2001: 13; change page to: 2001: 7 (Hieke, 2001).

Far Eastern taxa with ambiguous page numbers

The International Code of Zoological Nomenclature (ICZN, 1999) does not control the "primacy" of the page numbers where the taxon is described. The description is often published together with an identification key and if the key is given before the description, then an ambiguous situation arises: the taxonomic name, part of the diagnostic features, and sometimes the type locality/-ies of the new taxon is a page or more earlier than the full description. In this situation, subsequent authors behave in different ways. Some are guided by the simple princi- 
ple of the first introduction (that is, by the pages of the key), but others by the pages of the full description. Obviously, both the name and type locality/-ies, as well as characters can be found, for example, in an abstract; however, the common sense suggests that an abstract should not be taken as the first indication. Thus, we consider the principle of the first mention (which is followed by some authors of the Catalogue of Palaearctic Coleoptera) unsuccessful.

Reference to only one (first) page was formed in the taxonomic literature in the XVIII-XIX centuries, when complete descriptions rarely took more than one page. As a rule, modern publications include a detailed description of a taxon, its drawings or photographs, and often a key to similar taxa. Since the most important task of a catalogue lies in simplifying the search for the necessary information, we propose to depart from the tradition that has developed in the coleopterological literature, presenting all pages of the original description, as is common in taxonomic publications on Hymenoptera (Smith, 2001; Taeger et al., 2010; Smith, Tripotin, 2012; Zhao et al., 2012; Rosa et al., 2014; van Achterberg, Tabeli, 2014; Madl, 2017, etc.) and in some other groups. An example of such an indication for Carabidae are Habu'a (1967, 1973, 1978) monographs.

p. 61: Notiophilus fasciatus Mäklin, 1855, synonym reitteri Spaeth, 1900: 522; actually: 1900: 513 (key), 522 (description) (Späth, 1900).

p. 122: Carabus (Hemicarabus) macleayi macleayi Dejean, 1826, synonym coreensis Breuning, 1933b: 856; actually: 1933b: 131 (key), 857 (description) (Breuning, 1933).

p. 271: Dyschirius (Eudyschirius) gracilis gracilis (Heer, 1837), synonym pekinensis Kult, 1949b: 127; actually: 1949b: 127 (key), 132 (description) (Kult, 1949).

p. 334: Bembidion (Plataphus) lucillum sundukovi Toledano, 2008a: 19; actually: 2008a: 13 (key), 19 (description) (Toledano, 2008). p. 590: Cymindis, subgenus Orientoberus Sundukov, 2011:331; actually: 2011:318 (key), 331 (description) (Sundukov, 2011).

p. 603: Microlestes minutulus (Goeze, 1777), synonym longulus Reitter, 1901f: 379; actually: 1901f: 372 (key), 379 (description) (Reitter, 1901).

p. 626: Diplocheila, subgenus Submera Habu, 1956a: 58; actually: 1956a: 50 (key), 58 (description) (Habu, 1956a).

p. 626: Diplocheila, subgenus Submera Habu, 1956, synonym Shirahataia Habu, 1956a: 63; actually: 1956a: 50 (key), 63 (description) (Habu, 1956a).

p. 635: genus Lachnocrepis LeConte, 1853, synonym Eulachnocrepis Habu, 1956b: 96; actually: 1956b: 79 (key), 96 (description) (Habu, 1956b).

p. 658: Gyrochaetostylus atricomes (Bates, 1873), synonym piceonigrum Jedlička, 1936d: 50; actually: 1936d: 48 (key), 50 (description) (Jedlička, 1936b).

p. 714: Pterostichus (Feroperis) alexandrovi Lafer, 1979: 16; actually: 1979: 7 (key), 16 (description) (Lafer, 1979).

p. 714: Pterostichus (Feroperis) arsenjevi Lafer, 1979: 27; actually: 1979: 7 (key), 27 (description) (Lafer, 1979).

p. 714: Pterostichus (Feroperis) chechcirensis Lafer, 1979: 28; actually: 1979: 8 (key), 28 (description) (Lafer, 1979).

p. 714: Pterostichus (Feroperis) kurentzovi kurentzovi Lafer, 1979: 18; actually: 1979: 7 (key), 18 (description) (Lafer, 1979).

p. 714: Pterostichus (Feroperis) kurentzovi labzuki Lafer, 1979: 24; actually: 1979: 7 (key), 24 (description) (Lafer, 1979).

p. 714: Pterostichus (Feroperis) levadensis Lafer, 1979: 21; actually: 1979: 7 (key), 21 (description) (Lafer, 1979). 
p. 714: Pterostichus (Feroperis) procax decastriensis Lafer, 1979: 30; actually: 1979: 7 (key), 30 (description) (Lafer, 1979).

p. 714: Pterostichus (Feroperis) shingarevi maichensis Lafer, 1979: 19; actually: 1979: 7 (key), 19 (description) (Lafer, 1979).

p. 714: Pterostichus (Feroperis) shingarevi shingarevi Lafer, 1979: 23; actually: 1979: 7 (key), 23 (description) (Lafer, 1979).

p. 714: Pterostichus (Feroperis) vladivostokensis Lafer, 1979: 13; actually: 1979: 7 (key), 13 (description) (Lafer, 1979).

p. 734: Pterostichus (Phonias) morawitzianus (Lutshnik, 1922), synonym kultukus Jedlička, 1958d:238; actually: 1958d: 235 (key), 238 (descript) (Jedlička, 1958).

Misprints and inconsistencies for taxa from other regions

p. 56: Nebria (Paranebria) livida livida (Linnaeus, 1758); delete JA. This is incorrect for Japan, the only subspecies occurring in East Asia being N. livida angulata Bänninger, 1949 (Shilenkov, 1975).

p. 162: Add the following: Carabus (Ohomopterus) dehaanii nakagomei Kubota, 2010: 49 A: JA (Kyushu). Type locality: Japon, Osumi peninsula, Kagoshima Pref. (Kubota, 2010).

p. 305: Bembidion (Diplocampa) assimile Gyllenhal, 1810; delete JA. This western Palaearctic species does not occur in East Asia. An erroneous record from Japan (Hokkaido: Hamakoshi-mizu near Abashiri) belongs to $\mathrm{Habu}$ and Baba (1968). Another species of the subgenus Diplocampa was later found to inhabit Hokkaido: B. transparens prostratum (Motschulsky, 1844).

p. 344: Lymnastis yanoi Nakane, 1963; add NC. Location: "Thesong” (Pawłowski, 1974). p. 374: Add the following: Dracotrechus meridianus meridianus Uéno, 2011: 15 A: JA. Type locality: Getô-onsen, $750 \mathrm{~m}$ in altitude, Waga-chô of Iwate Prefecture in northeastern Honshu, Northeast Japan (Uéno, 2011).

p. 374: Add the following: Dracotrechus meridianus thermarum Uéno, 2011: 18 A: JA. Type locality: Tsunagi, $240 \mathrm{~m}$ in altitude, in Morioka-shi of Iwate Prefecture in northeastern Honshu, Northeast Japan (Uéno, 2011).

p. 421: Trechus (Epaphius) rivularis (Gyllenhal, 1810); add ES. T. nigricornis Motschulsky, 1844 is listed as a synonym of $T$. rivularis in the Catalogue, described from "montagnes prés de Kiakhta, au-delà du Baïcal", that is, ES (Motschulsky, 1844).

p. 500: Drypta (Drypta) japonica Bates, 1873; add NC SC. Locations: NC — "Kaesong city, Kaesong, Hotel Janamsan; North Pyongan Prov. Myo- hyang-san, Iaon-nam vally"; SC "Prov. Chejudo, Cheju-do, Halla-san, Songpanak, 750 m” (Park, Széll, 2004).

p. 652: genus Batenoplatynus Morvan, 1998: 18, type species: Batenoplatynus assamensis Morvan, 1999; change 1999 to 1998.

p. 666: genus Paranchodemus Habu, 1978a: 7, type species: Anchodemus calleides Bates, 1883; change Anchodemus to Anchomenus (Bates, 1883).

p. 671: genus Sperkanhir Morvan, 2010: 16, type species: Sperkanhir babaulti Louwerens, 1953; change to Colpodes babaulti Louwerens, 1953 (Louwerens, 1953).

p. 685: Myas, subgenus Trigonognatha Motschulsky, 1858, synonym Aurisma Fairmaire, 1889g: 9, type species: Aurisma delavayi Fairmaire, 1888; change 1888 to 1889.

p. 712: Add the following: Pterostichus (Eosteropus) matsunagai Morita, 2011: 21 A: JA. Type locality: Mt. Shauzo-yama, 1,750-1,830 
m alt., Hamamatsu-shi, Shizuoka Prefecture, Central Japan (Morita, 2011).

p. 712: Pterostichus (Eosteropus) noburai Morita, 2008; change noburai to noborui (Morita, 2008).

p. 731: Pterostichus (Petrophilus) dilutipes Motschulsky, 1844; add WS. Locations: north and center of West Siberia (Khobrakova et al., 2014).

p. 732: Pterostichus (Petrophilus) uralensis uralensis Motschulsky, 1850a: 56 (Eurypessus); change the genus Eurypessus to Euryperis. Originally described as Euryperis uralensis (Motschulsky, 1850).

p. 737: Pterostichus (Plectus) drescheri (Fischer von Waldheim, 1817); add KZ WS. Type locality: "jugo minori montium Altaicorum, prope fluvium Gorgon" (Fischer von Waldheim, 1817: 463); KZ WS (Dudko et al., 2002, 2010 , etc.).

p. 750: Stomis, subgenus Stomis Clairville, 1806, synonym Stobeus Fairmaire, 1889g: 8, type species: Stobeus collucens Fairmaire, 1888; change 1888 to 1889 .

p. 767, 771: Calathus (incertae sedis) prentus Jedlička, 1937f: 79 and Pristosia (Paradolichus) prenta Jedlička, 1937f: 79. This is the same taxon listed in the Catalogie as two different species in the subtribes Calathina and Pristosiina. Originally described as Calathus prentus (Jedlička, 1937).

p. 793: Synuchus (Synuchus) vivalis simplex Semenov, 1891; add KI KZ TD TM, delete NC. Widespread in the mountains of Central Asia; in East Asia, only the subspecies $S$. vivalis uenoi Lindroth, 1956 is found to occur.

\section{Conclusion}

Thus, taking into account the present paper, the fauna of the Far East of Russia currently includes 781 taxa of specific rank (700 species and 81 subspecies).

In addition to the updates in the list, some general comments on the systematic part of the Catalogue are necessary give. For example, in the directory:

- in the distributional data, errors such as "ES (Altai)" are often encountered, although Altai is part of western Siberia and should be cited as "WS (Altai)";

- there is no uniform writing of the names of G.G. Jakobson ("Jakobson" or "Jacobson");

- a lot of errors in recapitulating the proper genus for the first descriptions of taxa of the species rank, this raising doubts about unverified taxa;

- there is no uniform choice for the pages of a taxon's first description. We suggest that both the page containing the diagnosis and that from the key can be used.

Summarizing this study, it is worth noting that the section on ground beetles in the Catalogue of Palaearctic Coleoptera contains quite a few errors. Of the 761 taxa of the species rank listed in the Catalogue for the fauna of the Far East of Russia, our clarifications concern 145 species, subspecies or their synonyms. It appears that for a better preparation of such muchneeded and practically important documents as catalogues of animal and plant diversity, it is necessary to recruit more specialists. These specialists can even duplicate each other, both in taxonomy and assessing the diversity of local faunas. They can even be used if not as authors, then for consulting or as reviewers.

\section{Acknowledgements}

We are sincerely grateful to Dr. Alexei Gusakov (Zoological Museum of the Moscow University, Moscow) for his help in studying some literature sources.

\section{References}

Andrewes H.E. 1937. Papers on Oriental Carabidae XXXII // The Annals and Magazine of Natural History. Ser.10. Vol.20. P.561-576.

Ball G.E. 1966. A revision of the North American species of the subgenus Cryobius Chaudoir (Pterostichus, 
Carabidae, Coleoptera) // Opuscula Entomologica Supplementum. Vol.28. P.1-166.

Barševskis A. 2007. Biogeography of the genus Notiophilus Dumeril, 1806 (Coleoptera: Carabidae) // Baltic Journal of Coleopterology. Vol.7. No.1. P.121-135.

Bates H.W. 1873. Descriptions of new genera and species of geodephagous Coleoptera, from China// The Transactions of the Entomological Society of London. Vol.2[1873]. P.323-334.

Bates H.W. 1883. Supplement to the geodephagous Coleoptera of Japan, chiefly from the collection of $\mathrm{Mr}$. George Lewis, made during his second visit, from February, 1880, to September, $1881 / /$ The Transactions of the Entomological Society of London. Vol.1883. P.205-290, pl.xiii.

Bates H.W. 1888. On some new species of Coleoptera from Kiu-Kiang, China // Proceedings of the Scientific Meetings of the Zoological Society of London. Vol.56. P.380-383.

Bates H.W. 1889. On new species of the coleopterous families Cicindelidae and Carabidae, taken by $\mathrm{Mr}$. Pratt in Chang-Yang, near Tchang on the Yang-tsze, China // Proceedings of the Zoological Society of London. Vol.57. P.216-219.

Berlov E.Yu., Berlov O.E. 1997a. [The ground beetles (Coleoptera, Carabidae) of anthropogenic habitats of Khabarovsk] // Vestnik Irkutskoy Gosudarstvennoy Selskokhozyaystvennoy Akademii. Vol.4. P.51-52 [in Russian].

Berlov E.Yu., Berlov O.E. 1997b. [The ground beetles (Coleoptera, Carabidae) of Sakhalin Island] // Vestnik Irkutskoy Gosudarstvennoy Selskokhozyaystvennoy Akademii. Vol.4. P.52-54 [in Russian].

Berlov O., Plutenko A. 1997. Two new subgenera of the genus Pterostichus (Coleoptera, Carabidae) from the Far East of Russia // Vestnik Irkutskoy Gosudarstvennoy Selskokhozyaystvennoy Akademii. Vol.5. P.4751.

Bousquet Y. 2003. Tribe Pterostichini Bonelli, 1810 // I. Löbl, A. Smetana (eds.). Catalogue of Palaearctic Coleoptera. Vol. 1. Archostemata - Myxophaga Adephaga. Stenstrup: Apollo Books. P.469-521.

Bousquet Y. 2017. Tribe Pterostichini Bonelli, 1810 // I. Löbl, D. Löbl (eds.). Catalogue of Palaearctic Coleoptera. Vol. 1. Archostemata-Myxophaga-Adephaga. Revised and Updated Edition. Volume 1. Leiden - Boston: Brill. P. 675-755.

Breuning S. 1932. Monographie der Gattung Carabus L. // Bestimmungs-Tabellen der europäischen Coleopteren. H.104. Troppau: Emmerich Reitter. S.1-288.

Breuning S. 1933. Monographie der Gattung Carabus L. (IV. Teil) // Bestimmungs-Tabellen der europäischen Coleopteren. H.107. Troppau: Emmerich Reitter. S.707-912.

Březina B., Huber C., Marggi W. 2017. Subtribe Carabina Latreille, 1802 // I. Löbl, D. Löbl (eds). Catalogue of Palaearctic Coleoptera. Volume 1. Archostemata Myxophaga - Adephaga. Revised and Updated Edition. Vol. 1. Leiden - Boston: Brill. P.70-207.
Brinev A.E., Shilenkov V.G. 2001. [Ground beetles of the subgenus Tundraphilus, genus Pterostichus (Coleoptera, Carabidae)] // Zoologicheskii Zhurnal. Vol.80. No.7. P.797-808 [in Russian].

Budilov P.V. 2016. [To the fauna of ground beetles (Coleoptera, Carabidae) in the interfluve of Amur and Amgun rivers, Khabarovskii Krai] // Chteniya pamyati A.I. Kurentsova. Vladivostok. Vol.27. P.115120 [in Russian].

Casale A. 1988. Revisione degli Sphodrina (Coleoptera, Carabidae, Sphodrini). Torino: Museo Regionale di Scienze Naturali, Monografie V. 1024 p.

Chaudoir M. de 1868. Observations synonymiques sur les carabiques de 1'Amérique septentrionale et descriptions d'espèces nouvelles de ce pays // Revue et Magasin de Zoologie Pure et Appliquée. Vol.2. No.20. P.161-171, 211-217, 239-245, 283-301, 331-345.

Chaudoir M. de 1869. Descriptions de Calosoma nouveaux des collections de Mm. de Chaudoir et Salle // Annales de la Societe Entomologique de France. Vol.4. No.9. P. 367-378.

Dudko R.Y., Efimov D.A., Lomakin D.E. 2002. [Structure and specific features of the carabid fauna (Coleoptera, Carabidae) in the Kuznetskii Alatau and Gornaya Shoriya] // Zoologicheskii Zhurnal. Vol.81. No.6. P.664-677 [in Russian].

Dudko R.Yu., Matalin A.V., Fedorenko D.N. 2010. [The ground beetle fauna (Coleoptera, Carabidae) of the southeastern Altai] // Zoologicheskii Zhurnal. Vol.89. No.11. P.1312-1330 [in Russian].

Erjiomin P.K. 1998. [Species of the Pterostichus (Cryobius) brevicornis group (Coleoptera, Carabidae) of the Palaearctic] // Zoologicheskii Zhurnal. Vol.77. No.3. P.295-302 [in Russian].

Faldermann F. 1835a. Coleopterorum ab illustrissimo Bungio in China boreale, Mongolia et montibus Altaicus collectorum nec non ab ill. Turczaninoffio et Stschukino e provincia Irkutzk missorum illustrationes. Petropoli: Académie des Sciences de SaintPétersbourg. 128 p., 5 pls.

Faldermann F. 1835b. Coleopterorum ab illustrissimo Bungio in China boreale, Mongolia et montibus Altaicus collectorum, nec non ab ill. Turczaninoffio et Stschukino e provincia Irkutzk missorum illustrationes // Mémoires présentés à l'Académie Impériale des Sciences de Saint-Pétersbourg par divers savans et lus dans ses assemblées. Vol.2. P.337-464, pls.I-V.

Fedorenko D.N. 1991. [Carabids of the Dyschirius globosus species group (Coleoptera, Carabidae) from the Far East of the USSR] // Zoologicheskii Zhurnal. Vol.70. No.1. P.147-151 [in Russian].

Fedorenko D.N. 2003. New or little-known Dyschiriodes Jeannel, 1941 from Asia (Coleoptera: Carabidae) // Russian Entomological Journal. Vol.12. No.4. P.369372 .

Fischer von Waldheim G. 1817. De coleopteris quibusdam novis // Mémoires de la Société Impériale des Naturalistes de Moscou. Vol.5. P.463-471.

Fischer von Waldheim G. 1820. Entomographie de la Russie [Entomographia Imperii Russici]. Tome I. Moscou: A. Semen. 26 pls. 
Fischer von Waldheim G. 1823. Entomographie de la Russie [Entomographia Imperii Russici]. Suae Caesareae Majestati Alexandro I dicata. Tome II. Moscou: A. Semen. 40 pls.

Fischer von Waldheim G. 1828. Entomographie de la Russie [Entomographia Imperii Russici]. Tome III. Moscou: A. Semen. viii +314 p., 18 pls.

Gebler F.A. von 1823. Observationes entomologicae // Mémoires de la Société Impériale des Naturalistes de Moscou. Vol.6. P.115-131.

Gebler F.A. von 1833. Notae et addidamenta ad Catalogum Coleopterorum Sibiriae occidentale et confinis Tatariae operis, C.F. von Ledebours Reise in das Altaigebirge und soongarische Kirgisensteppe (Zweiter Theil. Berlin 1830) // Bulletin de la Société Impériale des Naturalistes de Moscou. Vol.6. P.262-309.

Géhin J.J.B. 1885. Catalogue synonymique et systematique des coléoptères de la tribu des carabides. Avec des planches dessinées par Ch. Haury. Remiremont: V. Jacquot. xxxviii+104 p., 10 pls.

Gemminger M., Harold E., von. 1868. Catalogus coleopterorum hucusque descriptorum synonymicus et systematicus. Tom. I. Cicindelidae-Carabidae. Monachii: E.H. Gummi. xxxvi+424+[8] p.

Habu A. 1956a. On the species of Diplocheila (Coleoptera, Carabidae) and its allied genera of Japan // The Bulletin of the National Institute of Agricultural Sciences. Series C. Vol.6. P.49-73.

Habu A. 1956b. On the genera and species of the Oodini (Coleoptera, Carabidae) from Japan // The Bulletin of the National Institute of Agricultural Sciences. Series C. Vol.6. P.75-101.

Habu A. 1967. Fauna Japonica. Carabidae Truncatipennes group (Insecta: Coleoptera). Tokyo: Biogeographical Society of Japan. xiv+338 p., 27 pls.

Habu A. 1972. On a species of Eupetedromus, a subgenus of Bembidion, found in Hokkaido, north Japan. (Coleoptera, Carabidae) // The Entomological Review of Japan. Vol.24. P.17-19.

Habu A. 1973. Fauna Japonica. Carabidae: Harpalini (Insecta, Coleoptera). Tokyo: Keigaku Publishing Co. xiii+430 p.

Habu A. 1978. Fauna Japonica. Carabidae: Platynini (Insecta: Coleoptera). Tokyo: Keigaku Publishing Co. vii+447 p., 36 pls.

Habu A. 1987. Classification of the Callistini of Japan (Coleoptera, Carabidae) // The Entomological Review of Japan. Vol.42. No.1. P.1-35.

Habu A., Baba K. 1968. An unrecorded and an undescribed species of Bembidion from Hokkaido, Japan, with the description of a new subgenus (Coleoptera, Carabidae) // Kontyû. Vol.36. P.144-146.

Heyden L., von. 1886. Die Coleopteren-Fauna des SuyfunFlusses (Amur) // Deutsche Entomologische Zeitschrift. Bd.30. S.269-277.

Hieke F. 1999. The Amara of the subgenus Reductocelia Lafer, 1989 (Coleoptera, Carabidae, Zabrini) // A. Zamotajlov, R. Sciaky (eds). Advances in Carabidology. Papers Dedicated to the Memory of Prof. Dr. Oleg L. Kryzhanovskij. Krasnodar: MUISO Publishers. P.333-362.
Hieke F. 2000. Revision einiger Gruppen und neue Arten der Gattung Amara Bonelli, 1810 (Coleoptera: Carabidae) // Annales Historico-Naturales Musei Nationalis Hungarici. Vol.92. P.41-143.

Hieke F. 2001. Das Amara-Subgenus Xenocelia subg. n. (Coleoptera: Carabidae) // Folia Heyrovskyana (Supplementum). Vol.7. P.1-153.

Hieke F. 2002. Neue Arten der Gattung Amara Bonelli 1810 (Coleoptera: Carabidae) // Linzer Biologische Beiträge. Bd.34. H.1. S.619-720.

Holdhaus K. 1912. Monographie der paläarktische-Arten der Coleopteren-Gattung Microlestes // Denkschrift der Kaiserlichen Akademie der Wissenschaften in Wien, Mathematisch-naturwissenschaftliche Klasse. Bd.88. S.1-64[477-540].

Hovorka O., Sciaky R. 2003. Subtribe Synuchina Lindroth, 1956 // I. Löbl, A. Smetana (eds). Catalogue of Palaearctic Coleoptera. Volume 1. Archostemata Myxophaga - Adephaga. Stenstrup: Apollo Books. P.544-547.

ICZN 1999. International Code of Zoological Nomenclature. Fourth Edition. London: The International Trust of Zoological Nomenclature. xxix+306 p.

Jeannel R. 1941. Coléoptères carabiques. Première partie. Faune de France 39. Paris: Librairie de la Faculté des Sciences. 571 p.

Jedlička A. 1936a. Über palaearktische Dolichus-Arten // Casopis Ceskoslovenské Společnosti Entomologiské. Vol.33. P.31-32.

Jedlička A. 1936b. Neue Colpodes-Arten aus Japan // Casopis Ceskoslovenské Společnosti Entomologiské. Vol.33. P.48-51.

Jedlička A. 1937. Calathus-Arten und ihre Verwandten aus China // Casopis Ceskoslovenské Společnosti Entomologiské. Vol.34. P.78-83.

Jedlička A. 1953. Neue palaarktische Carabiden aus der Sammlung des Ungarischen Naturwissenschaftlichen Museums (Coleoptera) // Annales Historico-Naturales Musei Nationalis Hungarici (S.N.). Vol.3[1952]. P.105-113.

Jedlička A. 1958. Přispěvek k poznani palaearktickych střevliců. Beitrag zur Kenntnis der palaearktischen Carabiden (Coleoptera) // Sbornik Entomologickeho Oddileni Narodniho Musea v Praze. Vol.32. P.223246.

Jedlička A. 1960. Neue Carabiden aus den Sammlungen des Ungarischen Naturwissenschaftlichen Museums in Budapest (Coleoptera) // Annales Historico-Naturales Musei Nationalis Hungarici. Vol.52. P.229233.

Jedlička A. 1965. Monographie des Tribus Bembidiini aus Ostasien (Coleoptera, Carabidae) // Entomologische Abhandlungen, Staatliches Museum für Tierkunde in Dresden. Bd.32[1964-1967]. S.79-199.

Kaizuka J., Iwasa M. 2014. Carabid beetles (Coleoptera: Carabidae) in coniferous plantations in Hokkaido, Japan: effects of tree species and environmental factors // Entomological Science. P.1-9.

Kataev B.M. 2006. On two species of the genus Pentagonica of the Russian fauna (Coleoptera: Carabidae) // 
Zoosystematica Rossica. Vol.15. No.2. P.305-307.

Khobrakova L.T., Shilenkov V.G., Dudko R.Y. 2014. [The ground beetles (Coleoptera, Carabidae) of Buryatia]. Ulan-Ude: Buryat Scientific Center SB RAS Press. 380 p. [In Russian]

Khruleva O.A. 1987. [Invertebrates] // V.E. Sokolov (ed). Flora i fauna zapovednikov SSSR. Fauna zapovednika "Ostrov Vrangelya". Moscow: VINITI. P.6-36 [in Russian].

Kirschenhofer E. 1984. Neue paläarktische Bembidiinae unter besonderer Berücksichtigung der von Eigin Suenson in Ostasien durchgeführten Aufsammlungen. 1. Teil: Bembidion Latreille // Koleopterologische Rundschau. Bd.57. S.57-92.

Komarov E.V. 1991. [Carabids of the genus Badister Clairv. (Coleoptera, Carabidae) in the fauna of the USSR]//Entomologicheskoe Obozrenie. Vol.70. No.1. P.93-108 [in Russian].

Koshkin E.S., Rogatnykh D.Y., Bezborodov V.G. 2016. [Ground beetles (Coleoptera: Carabidae) in the Bureinskii State Nature Reserve, Khabarovskii Krai, Russia]// Euroasian Entomological Journal. Vol.15. No.4. P.309-318 [in Russian].

Kraatz G. 1886. Ueber eine Caraben-Sendung von der Suyfun-Mündung vom Amur von F. und H. Dorries // Deutsche Entomologische Zeitschrift. Bd.30. S.257268.

Krivolutskaja G.O. 1973. [Entomofauna of the Kurile Islands]. Leningrad: Nauka Publ. 316 p. [In Russian]

Kryzhanovskij O.L. 1973. [New species] / O.L. Kryzhanovskij, L.P. Molodova. Faunisticheskie i ekologicheskie kompleksy zhuzhelits (Coleoptera, Carabidae) Yuzhnogo Sakhalina // Entomologicheskoe Obozrenie. Vol.52. P.63-75 [in Russian].

Kryzhanovskij O.L. 1976. [A review of ground-beetles of the tribe Callistini (Coleoptera, Carabidae) of the USSR Far East] // Nasekomye Dalnego Vostoka. Trudy Biologo-pochvennogo instituta DVO AN SSSR. T.43. No.146. P.8-17 [in Russian].

Kryzhanovskij O.L., Belousov I.A., Kabak I.I., Kataev B.M., Makarov K.V., Shilenkov V.G. 1995. A checklist of the ground-beetles of Russia and adjacent lands (Insecta, Coleoptera, Carabidae). Sofia-Moskow: Pensoft Publishers. P.1-271.

Kryzhanovskij O.L., Okhotina M.V., Bromlei G.F., Lafer G.S. 1975. [A review of the ground-beetles (Coleoptera, Carabidae) of the Kurile Islands] // Entomologicheskie issledovaniya na Dalnem Vostoke. Trudy Biologo-pochvennogo instituta DVO AN SSSR. T.28. No.3. P.119-142 [in Russian].

Kuberskaya O.V., Mutin V.A. 2016. [The ground beetles (Coleoptera, Carabidae) from Myao-Chan Ridge, Khabarovskii Krai] // Chteniya pamyati A.I. Kurentsova. Vladivostok. Vol.27. P.93-106 [in Russian].

Kubota K. 2010. Discovery of Carabus (Ohomopterus) dehaanii Chaudoir, 1848 (Coleoptera, Carabidae) from the Ôsumi Peninsula, Kyushu, Japan: description of a new subspecies // Biogeography. Vol.12. P.49-52.

Kult K. 1949. Revision of the genus Dyschirius, Bon., species from S.E. Asia (Col. Carabidae) (21st contri- bution) // Casopis Ceskoslovenské Společnosti Entomologiské. Vol.46. P.122-132.

Kuwayama S. 1967. Insect fauna of the southern Kurile Islands. Sapporo. $225 \mathrm{p}$.

Lafer G.S. 1973. [On little-known ground-beetles (Coleoptera, Carabidae) of the Maritime Territory and their zoogeographic characteristics] // Entomologicheskoe Obozrenie. Vol.52. P.845-855 [in Russian].

Lafer G.S. 1979. [The ground beetles of the subgenus Feroperis nov., genus Pterostichus Bon. (Coleoptera, Carabidae)] // Zhuki Dal'nego Vostoka i Vostochnoy Sibiri: novye dannye po faune i sistematike. Vladivostok: DVO AN SSSR. P.3-35 [in Russian].

Lafer G.S. 1980. [Review of the carabid sungenera Bradytus Steph. and Leiocnemis Zimm. (Coleoptera, Carabidae) of the USSR Far East] // P.A. Lehr (ed). Taksonomiya nasekomykh Dalnego Vostoka. Vladivostok: DVO AN SSSR. P.43-68 [in Russian].

Lafer G.S. 1989. [4. Family Carabidae - The Groundbeetles] // P.A. Lehr (ed). Opredelitel nasekomykh Dalnego Vostoka SSSR. T.3. Zhestkokrylye, ili zhuki. Part 1. Leningrad: Nauka Publ. P.71-222 [in Russian].

Lafer G.S. 1992a. [4. Fam. Carabidae - The Groundbeetles. Agonum Bon.] // P.A. Lehr (ed.). Opredelitel nasekomykh Dalnego Vostoka SSSR. T.3. Zhestkokrylye, ili zhuki. Part 2. St. Petersburg: Nauka Publ. P.602-621 [in Russian].

Lafer G.S. 1992b [Addendum. On the distribution of the species of the genus Pterostichus from the subgenus Feroperis in the South-East of Amurskaya oblast and their morphological characteristics] // Yu.A. Chistyakov (ed.). Nasekomye Khinganskogo zapovednika. Part 1. Vladivostok: Dalnauka. P.81-94 [in Russian].

Lafer G.S. 1996. [Fam. Carabidae - The Ground-beetles. Additions]// P.A. Lehr (ed.). Opredelitel nasekomykh Dalnego Vostoka Rossii. T.3. Zhestkokrylye, ili zhuki. Part 3. Vladivostok: Dalnauka. P.396-408 [in Russian].

Lafer G.S. 2002. [Ground beetles (Coleoptera, Carabidae) of southern oceanic islands of the Great Kurile Ridge] // Euroasian Entomological Journal. Vol.1. P.47-66 [in Russian].

Lafer G.S. 2004. [Ground beetles] // A.N. Tyurin (ed.). Dal'nevostochnyi Morskoi biosfernyi zapovednik. Biota. T.2. Vladivostok: Dalnauka. P.711-719 [in Russian].

Lafer G.S. 2005. A check-list of ground beetles (Coleoptera: Cicindelidae, Carabidae) of the MuravjevAmursky Peninsula, Primorskii Krai // Far Eastern Entomologist. No.151. P.1-8.

Lafer G.S. 2006. [Ground-beetles (Coleoptera: Cicindelidae, Carabidae) of Moneron Island] // Rastitelnyi i zhivotnyi mir ostrova Moneron (Materialy Mezhdunarodnogo Sakhalinskogo proekta). Vladivostok. P.218-227 [in Russian].

Lafer G.S. 2011. [To the fauna of carabid beetles (Coleoptera: Caraboidea) of Sakhalin: Erroneously recorded taxa] // Chteniya pamyati A.I. Kurentsova. Vladivostok. Vol.22. P.181-189 [in Russian]. 
Lafer G.S., Budilov P.V. 2015. [New subspecies of Pterostichus orientalis (Motschulsky, 1844) (Coleoptera: Carabidae) from Primorskii Krai] // Chteniya pamyati A.I. Kurentsova. Vladivostok. Vol.26. P.101-108 [in Russian].

Löbl I., Löbl D. (eds.). 2017. Catalogue of Palaearctic Coleoptera. Volume 1. Archostemata - Myxophaga Adephaga. Revised and Updated Edition. Volume 1. Leiden - Boston: Brill. XXXIV+1443 p.

Louwerens C.J. 1953. The Oriental species of Colpodes Macl. (Col. Carabidae) // Treubia. Vol.22. P.75-151.

Lyubechanskii I.I., Dudko R.Y., Trilikauskas L.A. 2006. [Carabid beetle distributions (Coleoptera, Carabidae) among the typical biotopes of the Bureinskii State Nature Reserve (Khabarovsk Province, Russia)] // Entomologicheskie issledovaniya v Severnoy Azii. Novosibirsk. P.100-101 [in Russian].

Madl M. 2017. A catalogue of the family Stephanidae (Stephanoidea) of the Malagasy subregion (Insecta: Hymenoptera) // Linzer biologische Beiträge. Bd.49. H.1. S.21-28.

Maindron M. 1910. Descriptions de deux Dolichus nouveaux du Yunnan (Col. Carabidae) // Bulletin de la Société Entomologique de France. Vol.[1910]. P.1517.

Makarov K.V., Sundukov Yu.N. 2011. First record of Euplynes batesi and Agonum lampros (Coleoptera: Carabidae, Platynini) from Russia // Far Eastern Entomologist. No.234. P.34-36.

Makarov K.V., Sundukov Yu.N. 2016. Distribution and biology of the ground beetle Carabus (Damaster) blaptoides rugipennis (Motschulsky, 1861) on $\mathrm{Ku}-$ nashir Island, Kurile Islands, Russia // Nature Conservation Research. Vol.1. No.3. P.44-52.

Mäklin F.W. 1855. Bidrag till kännedom om såkallade vikarierande former bland Coleoptera i norden. Dissertation Helsingfors (Frenckell). 55 p.

Mäklin F.W. 1857. Beitrag zur Kenntnis der sogenannten vicarirenden Formen unter den Coleopteren des Nordens // Entomologische Zeitung. Bd.18. S.321-348.

Mandl K. 1954. Eine neue Acoptolabrus constricticollis Kraatz-Morpha in der Sammlung Georg Frey, Tutzing // Entomologische Arbeiten aus dem Museum G. Frey. Bd.5. S.397-398.

Mandl K. 1955. Ergebnisse einer Revision der CarabidenSammlung des Naturhistorischen Museums Wien // Annalen des Naturhistorischen Museums in Wien. Bd.60. S.236-272.

Matsumura S. 1911. Erster Beitrag zur Insecten-Fauna von Sachalin // The Journal of the Sapporo Agricultural College. Vol.4. No.1. P.1-145.

Morawitz A. 1862. Vorläufige Diagnosen neuer Coleopteren aus Südost-Sibirien // Mélanges Biologiques tirés du Bulletin de l'Académie des Sciences de St.Pétersburg. Vol.4. P.180-228 [Bulletin de l'Académie des Sciences de St.-Pétersburg. Vol.5. P.231-265].

Morawitz A. 1863. Beitrag zur Käferfauna der Insel Jesso. Erste Lieferung. Cicindelidae et Carabici // Mémoires de l'Académie Impériale des Sciences de St.-Pétersburg. Sér.7. Vol.6. No.3. P.1-84.
Mordkovich V.G. 2003. Spatial distribution of arthropods along the seashore catena of the Kunashir island (the Kurils) // Russian Entomological Journal. Vol.12. No.1. P.1-9.

Morita S. 2002. Pterostichine carabid beetles of the subgenus Cryobius (Coleoptera, Carabidae) from North Japan // Elytra. Vol.30. P.73-89.

Morita S. 2008. Notes on the pterostichine subgenus Eosteropus (Coleoptera, Carabidae) from Japan. Part 2. A new species from the Tohoku District, with a note on the cotype of Pterostichus fuligineus // Elytra. Vol.36. P.205-208.

Morita S. 2011. Notes on the pterostichine subgenus Eosteropus (Coleoptera, Carabidae) from Japan. Part 5. A new species from central Japan // S. Kawai (ed). Entomological papers dedicated to Dr. Kimio Masumoto on the occasion of his retirement. Masamushi. Special Publication of the Japanese Society of Scarabaeoidology. Vol.1. P.83-87.

Motschulsky V. de 1844. Insectes de la Sibérie rapportés d'un voyage fait en 1839 et 1840 // Mémoires de 1'Académie Impériale des Sciences de St.-Pétersburg. Vol.5. P.1-274+i-xv, 1-10 pls.

Motschulsky V. de 1850. Die Käfer Russlands. I. Insecta Carabica. Moskau: Buchdruckerei von W. Gautier. iv+ix+91 p., 1 map.

Motschulsky V. de 1859. Catalogue des insectes rapportés des environs du fl. Amour, depuis la Schilka jusqu'à Nikola,vsk // Bulletin de la Société Impériale des Naturalistes de Moscou. Vol.32. P.487-507.

Motschulsky V. de 1860. Coléoptères de la Sibérie orientale et notamment en particulier des rives de l'Amour // L. Schrenck, von (Hrsg.). Reisen und Forschungen im Amur-Lände in den Jahren 1854-1856 im Auftrage der Kaiserl. Akademie der Wissenschaften zu St. Petersburg. Zweiter Band. Zoologie: Lepidopteren, Coleopteren, Mollusken. Band 2. Coleopteren. St. Petersburg: Kaiserlichen Akademie der Wissenschaften. P.77-257, errata, 6-11 pls., 1 map.

Motschulsky V. de 1861. Entomologie speciale. Insectes du Japon (Continuation) // Etudes Entomologiques. Vol.9[1860]. P.4-39.

Motschulsky V. de 1864. Énumération des nouvelles espèces de coléoptères rapportés de des voyages. 4-ème article. Carabicines // Bulletin de la Société Impériale des Naturalistes de Moscou. Vol.37. P.171-240.

Netolitzky F. 1939. Beitrage zur Kenntnis der BembidionArten des Fernen Ostens (Japan, Korea, Ostsibirien) (Coleoptera). 3. Mitteilung // The Proceedings of the Royal Entomological Society of London. Ser.B. Vol.8. P.49-51.

Netolitzky F. 1943. Bestimmungstabellen europäischer Käfer (9. Stück). II. Fam. Carabidae. Subfam. Bembidiinae. 66. Gattung: Bembidion Latr. Bestimmungstabelle der Bembidion-Arten des paläarktischen Gebietes. (Mit Hinweisen auf holarktische, äthiopische und orientalische Arten) // Koleopterologische Rundschau. Bd.29. S.1-70.

Nicolai E.A. 1822. Dissertatio inauguralis medica sistens Coleopterorum species agri Halensis quam consensu 
illustrissimi medicorum ordinis in celeberrima Academia Fridericiana Halensi et Vitebergensi consociata pro summis in medicina et chirurgia honoribus rite obtinendis die X. mentis septembris MDCCCXXII publice defendet. Halae: Grunert. 48 p.

Obydov D. 1999. Review of the Megodontus group of the genus Carabus Linné of Sibiria (Coleoptera: Carabidae)//Coleoptera, Schwanfelder Coleopterologische Mitteilungen. Bd.3. S.83-130.

Panzer G.W.F. 1796. Faunae Insectorum Germanicae initia; oder Deutschlands Insecten. [Heft 40.] Nurnberg: Felsecker. 24 S., 24 pls.

Park J.K., Széll G. 2004. North Korean ground-beetles deposited in Hungarian National History Museum (HNHM, Budapest) // Entomological Research. Vol.34. No.3. P.213-224.

Pawłowski J. 1974. Tachyini (Coleoptera, Carabidae) of North Korea // Acta Zoologica Cracoviensia. Vol.19. P.155-196.

Paykull G., von. 1790. Monographia caraborum Sueciae. Upsaliae: J.F. Edman. [5]+138 p.

Poppius B. 1906. Beiträge zur Kenntnis der ColeopterenFauna des Lena-Thales in Ost-Sibirien. II. Cicindelidae und Carabidae // Öfversigt af Finska VetenskapsSocietetens Förhandlingar. Vol.48. No.3. P.1-65.

Putzeys J.A.A.H. 1875. Notice sur les carabiques recueillis par M. Jean van Volxem à Ceylan, à Manille, en Chine et au Japon (1873-1874) // Bulletin de la Société Entomologique de Belgique. Vol.1875. P.xlvliii.

Reitter E. 1887. Neue Coleopteren aus Europa, den angrenzenden Ländern und Sibirien, mit Bemerkungen über bekannte Arten. Vierter Theil // Deutsche Entomologische Zeitschrift. Bd.31. P.497-528.

Reitter E. 1901. Revision der Coleopteren-Gattung Blechrus Motsch. aus Europa und russisch Asien // Deutsche Entomologische Zeitschrift. Bd.[1900]. S.369380.

Roeschke H. 1907. Monographie der Carabiden-Tribus Cychrini // Annales Historico-Naturales Musei Nationalis Hungarici. Vol.5. P.99-277.

Rogatnykh D.Y. 2007. [New records of ground beetles (Coleoptera, Carabidae) from the Amur Region] // Euroasian Entomological Journal. Vol.6. No.4. P.493495 [in Russian].

Rogatnykh D.Y., Koshkin E.S. 2011. First record of Scarites terricola Bonelli, 1813 (Coleoptera: Carabidae) from Evreiskaya Avtonomnaya Oblast, Russian Far East // Far Eastern Entomologist. No.228. P.11-12.

Rosa P., Wei N.S., Xu Z.F. 2014. An annotated checklist of the chrysidid wasps (Hymenoptera, Chrysididae) from China // ZooKeys. Vol.455. P.1-128.

Sahlberg R.F. 1844. On faunam insectorum rossicam symbola, novas ad Ochotsk lectas carabicorum species continens // Acta Societatis Scientiarum Fennicae. Vol.3. P.1-69.

Sasakawa K., Kubota K. 2007. Phylogeny and genital evolution of carabid beetles in the genus Pterostichus and its allied genera (Coleoptera: Carabidae) inferred from two nuclear gene sequences // Annals of the
Entomological Society of America. Vol.100. No.2. P.100-109.

Semenov A.P. 1912. De novo Chlaeniinorum genere e fauna Imperii Rossici (Coleoptera, Carabidae) // Russkoe Entomologicheskoe Obozrenie. Vol.12. P.601-603.

Semenov A.P., Znojko D.V. 1932. Nouvelles données à l'étude de genre Carabus (L.) (Coleoptera, Carabidae), IV // Doklady Akademiy Nauk SSSR. P.215-218.

Shilenkov V.G. 1975. [Taxonomic review of the genus Nebria Latr. (Coleoptera, Carabidae) from Siberia and the Far East of the USSR] // Entomologicheskoe Obozrenie. Vol.54. P.830-845 [in Russian].

Shilenkov V.G. 1979. [New data on the ground beetle fauna (Coleoptera, Carabidae) of southern Transbaikalia] // Zhuki Dal'nego Vostoka i Vostochnoy Sibiri: novye dannye po faune i sistematike. Vladivostok: DVO AN SSSR. P.36-57 [in Russian].

Shilenkov V.G., Anichtchenko A.V. 1998. [Interesting faunistic findings of carabids (Coleoptera, Carabidae) in the Baikal Region] // Entomologicheskie problemy Baikalskoi Sibiri. Novosibirsk: Nauka Publ. P.94101 [in Russian].

Silfverberg H. 1987. Lists of the insect types in the Zoological Museum, University of Helsinki. 2. Coleoptera: Carabidae // Acta Entomologica Fennica. Vol.48. P.11-31.

Smith D.R. 2001. World catalog of the family Aulacidae (Hymenoptera) // Contributions on Entomology, Internation. Vol.4. No.3. P.263-319.

Smith D.R., Tripotin P. 2012. Trigonalidae (Hymenoptera) of Madagascar // Journal of Hymenoptera Research. Vol.24. P.1-25.

Späth F. 1900. Uebersicht der paläarktischen Arten des Genus Notiophilus Dumeril // Verhandlungen der Kaiserlich-königlichen Zoologisch-botanischen Gesellschaft in Wien. Bd.49[1899]. S.510-523.

Sundukov Yu.N. 2001a. [New data on the carabid fauna (Coleoptera, Carabidae) of the Russian Far East] // Zoologicheskii Zhurnal. Vol.80. P.754-757 [in Russian].

Sundukov Yu.N. 2001b. [Two new species of the genus Curtonotus Stephens (Coleoptera, Carabidae) from the south of the Russian Far East] // Entomologicheskoe Obozrenie. Vol.80. P.436-442 [in Russian].

Sundukov Yu.N. 2003. [The ground beetle fauna (Coleoptera, Caraboidea) of the Sikhote-Alinsky State Nature Reserve] // Euroasian Entomological Journal. Vol.2. No.2. P.109-115 [in Russian].

Sundukov Yu.N. 2005. [A review of species of the subgenus Lenapterus (Coleoptera, Carabidae, Pterostichus), with description of a new species and a new subspecies from Sikhote-Alin Mountains] // Zoologicheskii Zhurnal. Vol.84. P.803-825 [in Russian].

Sundukov Yu.N. 2008. [Species of the subgenus Baudia of the genus Badister (Coleoptera, Carabidae) from the southern Sikhote-Alin Mountains] // Zoologicheskii Zhurnal. Vol.87. P.1313-1318 [in Russian].

Sundukov Yu.N. 2009a. [Family Carabidae]// S.Yu. Storozhenko (ed.). Nasekomye Lazovskogo zapovednika. Vladivostok: Dalnauka. P.88-109 [in Russian]. 
Sundukov Yu.N. 2009b. [New data on the ground-beetle fauna (Coleoptera, Carabidae) of the Sikhote-Alin Mountains] // Zoologicheskii Zhurnal. Vol.88. P.2326 [in Russian].

Sundukov Yu.N. 2011. [A review of the genus Cymindis Latreille, 1806 (Coleoptera, Carabidae, Lebiini) of East Asia]// Amursky Zoologicheskii Zhurnal. Vol.3. P.315-344 [in Russian].

Sundukov Yu.N. 2013. [An annotated catalogue of the ground beetles (Coleoptera: Caraboidea) of the SikhoteAlin]. Vladivostok: Dalnauka. 271 p. [In Russian]

Sundukov Yu.N. 2014. [Features of the formation of the modern ground beetle fauna (Coleoptera, Carabidae) of Shikotan Island, Kuriles] // Chteniya pamyati A.I. Kurentsova. Vladivostok. Vol.25. P.25-33 [in Russian].

Sundukov Yu.N. 2017. [The ground beetles (Coleoptera, Carabidae) of the Yuri Island, southern Kuriles] // Chteniya pamyati A.I. Kurentsova. Vladivostok. Vol.28. P.101-110 [in Russian].

Sundukov Yu.N., Makarov K.V. 2013. [The ground beetles (Coleoptera, Carabidae) of Shikotan Island, Kurile Islands, Russia] // Euroasian Entomological Journal. Vol.12. P.339-348 [in Russian].

Sundukov Yu.N., Makarov K.V. 2016. New or littleknown ground beetles (Coleoptera: Carabidae) of Kunashir Island, Kurile Islands, Russia // Russian Entomological Journal. Vol.25. No.2. P.121-160.

Sundukov Yu.N., Smirnov M.E. 2010. First record of Pentagonica daimiella (Coleoptera: Carabidae) from Primorskii Krai // Far Eastern Entomologist. No.218. P.8.

Suzuki S. 2018. All species of beetles in the Japanese archipelago (2018). https://japanesebeetles.jimdo.com

Taeger A., Blank S.M., Liston A.D. 2010. World catalog of Symphyta (Hymenoptera) // Zootaxa. Vol.2580. P.1-1064.

Toledano L. 2008. Systematic notes on the Palaearctic Bembidion Latreille, 1802 (Coleoptera, Carabidae) with particular reference to the fauna of China // Memorie del Museo Civico di Storia Naturale di Verona (II serie), Sezione Scienze della vita. Vol.18. P.5-46.
Toledano L., Schmidt J. 2010. Revision of the Bembidion kara Andrewes, 1921 species group and notes on the Palaearctic species of Bembidion subgenus Trichoplataphus Netolitzky, 1914 (Coleoptera, Carabidae, Bembidiini)//Entomologische Blätter. Bd.106. S.371406.

Uéno S.-I. 1984. Additions to the trechine fauna of Northeast Japan (Coleoptera, Trechinae) // Bulletin of the National Science Museum, Tokyo. Series A. Vol.10. P.135-143.

Uéno S.-I. 2011. New blind trechine beetles belonging to the Kurasawatrechus-complex (Coleoptera, Trechinae) from Northeast Japan II. Species from the Ôwu Mountains // Elytra. New Series. Vol.1. No.1. P.15-20.

Uéno S.-I., Lafer G.S. 1994. Two relatives of Trechus nakaguroi (Coleoptera, Trechinae) with notes on the Trechus fauna of northeast Asia // Bulletin of the National Science Museum, Tokyo. Series A. Vol.20. P.111-126.

van Achterberg C., Talebi A.A. 2014. Review of Gasteruption Latreille (Hymenoptera, Gasteruptiidae) from Iran and Turkey, with the description of 15 new species // ZooKeys. Vol.458. P.1-187.

Vertyankin A.V., Shabalin S.A. 2013. [Provisional data on the population and domination of ground beetles (Coleoptera, Carabidae) in the meadows of southern Sakhalin Island] // Chteniya pamyati A.I. Kurentsova. Vladivostok. Vol.24. P.179-188 [in Russian].

Yokoyama K., Kanô T. 1927. List of Coleoptera hitherto been found in southern Saghalien // Zoological Magazine, Tokyo. Vol.39. No.459. P.1-39.

Yoshitake H., Kurihara T., Yoshimatsu S.I., Nakatani Y., Yasuda K. 2011. A list of carabid specimens (Insecta: Coleoptera) collected by the late Dr. Akinobu Habu preserved in the Insect Museum of the National Institute for Agro-Environmental Sciences // Bulletin of the National Institute for Agro-Environmental Sciences. Vol.28. P.1-327.

Zhao K.X., van Achterberg C., Xu Z.F. 2012. A revision of the Chinese Gasteruptiidae (Hymenoptera, Evanioidea) // ZooKeys. Vol.237. P.1-123.

Responsible editor K.G. Mikhailov 